Institute of $\mathbf{F}_{\text {ood and }} \mathbf{A}_{\text {gricultural }} \mathbf{S}_{\text {ciences }}$

\title{
The Trading Game (T-Game) ${ }^{1}$
}

\section{John J. VanSickle and Amir Drusbosky²}

The Trading Game (T-Game) program is a tool to help students and industry practitioners learn more about trading commodities on the futures exchanges. The T-Game was designed by John VanSickle, Director of the International Agricultural Trade and Policy Center, Department of Food and Resource Economics, Institute of Food and Agricultural Sciences, University of Florida. The T-Game simulation is available at http://tgame.ifas.ufl.edu.

The T-Game is a commodity-trading simulator that allows users to buy and sell commodity futures contracts, using delayed quotes from the commodity exchanges. The available commodities information comes from the Chicago Board of Trade, the Chicago Mercantile Exchange, and the New York Board of Trade. Currently, only agricultural contracts are traded.

This program is used in classrooms by universities and county Extension offices around the country (e.g., the University of Florida and Auburn University). Its use of nearly-real-time data makes it unique among the futures simulations available. The T-Games web-based interface allows professors to monitor the progress of their students, and allows students access to their individual accounts from any computer with an Internet connection.
The T-Game performs the brokerage functions with which a typical trader would deal if trading these commodities in the real world. Transactions are submitted by the trader on an electronic form that is a part of the simulation. The T-Game first checks the account status of the trader to ensure there are sufficient funds to support the trading fees and the margin requirements for that trade and grabs a current price quote to complete the trade. Once a trade is executed, the T-Game then tracks the account by monitoring the current status of all open positions and the amount of money available for trading. In addition, the simulation does a nightly maintenance routine which checks the current status of the account to ensure there is sufficient capital to meet the maintenance margin requirements for all current open positions given the daily settlement price for each contract. The T-Game also keeps a log of all transactions for each account. When the trading period ends, the instructor is given a report for each trader and a summary of activity for all traders.

Currently, the T-Game is being expanded to allow trading of more contracts from a greater number of exchanges. Additional products include metals, energy, and financial contracts from the Minneapolis Grain Exchange, Kansas City Board of

1. This is EDIS document FE368, a publication of the Department of Food and Resource Economics, Florida Cooperative Extension Service, Institute of Food and Agricultural Sciences, University of Florida, Gainesville, FL. Published January 2003. Please visit the EDIS website at http://edis.ifas.ufl.edu.

2. John J. VanSickle, Professor and Director, International Agricultural Trade and Policy Center, Department of Food and Resource Economics; and Amir Drusbosky, OPS Technical, UF-FACTS Project, Department of Food and Resource Economics, Florida Cooperative Extension Service, Institute of Food and Resource Economics, Institute of Food and Agricultural Sciences, University of Florida, Gainesville, FL.

The Institute of Food and Agricultural Sciences is an equal opportunity/affirmative action employer authorized to provide research, educational information and other services only to individuals and institutions that function without regard to race, color, sex, age, handicap, or national origin. For information on obtaining other extension publications, contact your county Cooperative Extension Service office. Florida Cooperative Extension Service/Institute of Food and Agricultural Sciences/University of Florida/Christine Taylor Waddill, Dean. 
Trade, New York Mercantile Exchange, etc. The forthcoming version will also move to a faster data feed, bringing the price delay down to a number of milliseconds.

The T-Game is an invaluable tool to anyone who wishes to learn more about the futures and options markets. Its use in the classroom is growing at the University of Florida and other institutions around the country. 